\title{
Flow regulation at constant head in feedwater pumps in a sugar industry
}

\author{
Julio R. Gómez ${ }^{1}$, Vladimir Sousa ${ }^{2}$, Mario S. Quintana ${ }^{3}$, Percy R. Viego ${ }^{4}$, Hernán Hernández ${ }^{5}$, \\ Enrique C. Quispe ${ }^{6}$ \\ ${ }^{1,3,4}$ Center of Energy and Environmental Studies Department, Universidad de Cienfuegos, Cuba \\ ${ }^{2}$ Energy Department, Universidad de la Costa, Calle 58 No.55-66, Barranquilla, Colombia \\ ${ }^{5}$ Facultad de Ingenierias, Universidad Simon Bolivar, Colombia \\ ${ }^{6}$ Energy and Mechanical Department, Universidad Autónoma de Occidente, Colombia
}

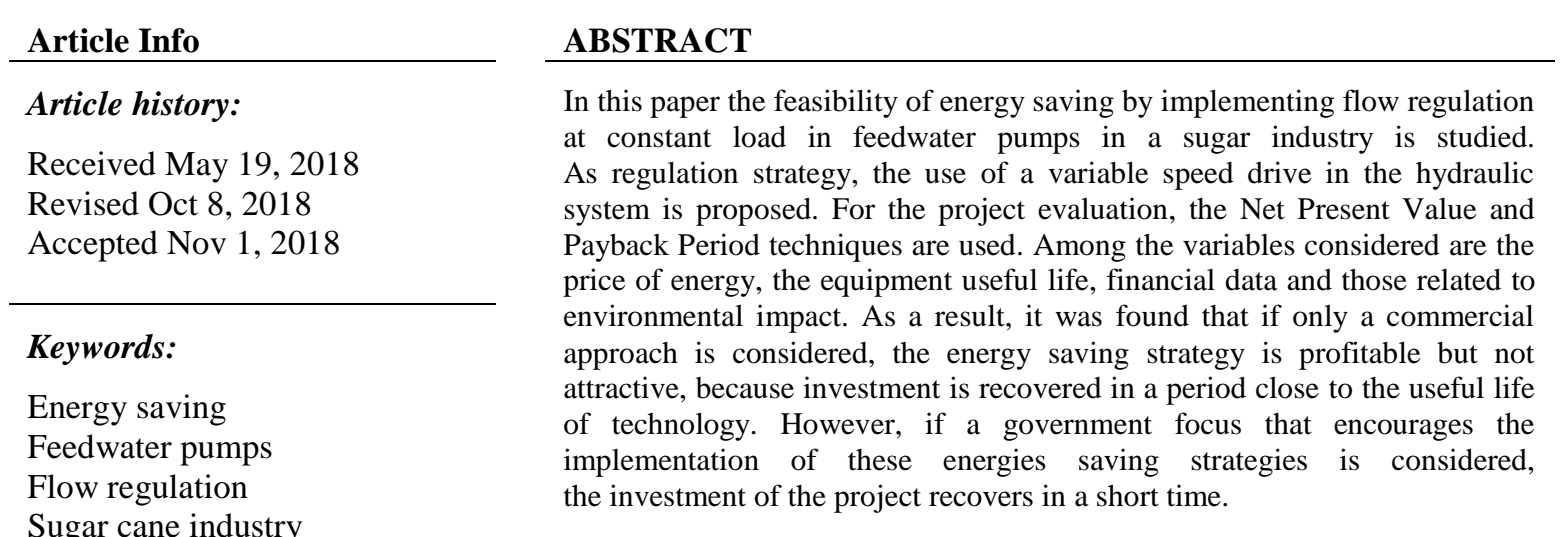

Copyright $@ 2019$ Institute of Advanced Engineering and Science. All rights reserved.

\section{Corresponding Author:}

Vladimir Sousa Santos, Energy Department, Universidad de la Costa, Calle 58 No.55-66, Barranquilla, Colombia.

Email: vsousa1@cuc.edu.co

\section{INTRODUCTION}

Worldwide energy consumption increased around a 10.5\%, from 2010 to 2016. In this scenario, the industrial sector is the largest consumer with about $54 \%$ of the total energy consumption. In the period from 2012 to 2040 the continuity of this trend is foreseen, with an increase in total energy consumption by $39 \%$, and the industry consuming half of this energy [1].

Three types of industries can be categorized according to the use of energy: energy-intensive manufacturing industries, non-energy-intensive manufacturing industries, and non-manufacturing [1]. Energy-intensive manufacturing industries accounts more than a half of total delivered energy in industrial sector; therefore, the evaluation of energy efficiency in these plays an important role in different countries [2].

Sugar mills is an energy-intensive industry that demand large amounts of electrical and thermal energy to transform raw materials into final products. In recent years, low market prices of sugar have affected the levels of profits, so they have begun to implement strategies to increase their competitiveness [3].

In the past, sugar industry produced only sugar but nowadays includes electricity and ethanol. So, sugar industry is now called as the cane industry [4]-[6]. The efficient use of energy is one of the priorities in the sugar mills and has been classified into three groups: high efficiency mills (less than $450 \mathrm{~kg}$ 
steam/ tons of cane), medium efficiency mills (between 450 and $600 \mathrm{~kg}$ steam/ tons of cane), and low efficiency mills (more than $600 \mathrm{~kg}$ steam/ tons of cane) [7].

Among the total energy demand in the industries, nearly $70 \%$ is consumed by motors [8]-[10], of these, $20 \%$ drive pumps. Energy efficiency in pump systems can be improved between 5-50 \% by proper maintenance, correct design an adequate control methods. The use of variable speed drive, encouraged by the decrease in their prices, is one of the main measures being implemented [11]-[13].

Numerous studies have focused on energy saving based on optimization in the design of the hydraulic and control systems. In [11], [14], [15], it is proposed to reduce the losses in a parallel pumping system with a common collector in the discharge, by optimizing the distribution of the flow in each pump. Strategies based on pressure differentials, especially for centralized air conditioning systems with variable flow in buildings, has been analyzed in [16], [17]. Control system based on fuzzy logic to maintain the flow against large perturbations in the parameters of the system, keeping the pump operating in the region of maximum efficiency was proposed in [18]. Further studies are aimed to the design of sophisticated control strategies [19]-[21].

Also, some research has been directed to the development of simulation and optimization models and tools, widely used for the analysis of pumping systems with primary motors operating at different speeds. For instance, in [22], a model of a centrifugal pump driven by a single-phase motor of different speeds is developed. The model was implemented in Matlab-Simulink and it's used for study the behaviour of the most important variables, such as: motor and load torque, angular velocity, delivered pressure and current consumed by the motor. Other tools focus on simulating the operation of pumping stations, in order to help define the best regulation and control strategy [23].

One of the strategies that most stands out in the scientific literature and is object of study in this work, are the flow control strategies with constant pressure. Among the advantages of these strategies are a better distribution of water, energy savings and longer life of the equipment, increasing the economic benefits [24].

In the Cuban sugar industry, these flow regulation methods have been analyzed in pumping systems of different fluids within the process. An example is the evaluation of the electric drive systems efficiency in sugar mills based on their level of automation and the use of variable speed drive. The study showed that with the installation of variable speed drive, the efficiency improves by $11 \%$ and the energy consumption decreases by approximately $25 \%$ [24], [25]. Other experiences are reported for the case of juice pumps with satisfactory results from the point of view of energy saving [26].

Specifically, for the control of the water flow of boiler feed, a study showed the technical feasibility of regulating the capacity with variable speed drive of the water pumps to feed a thermoelectric power plant, resulting in the regulation method frequency variation meant a saving of \$ 483317 / year [27]. This aspect has not been deepened in water systems to feed boiler batteries in the process industry.

The water supply system to the boilers of sugar factories aims to maintain the level of steam generators domes. In many mills, this is achieved by a valve that regulates the passage of water according to the need for steam generation. This system can be replaced by variable speed drives which would reduce the energy consumption between 30 and 50\%, increase process control and system reliability [28], [29]. In addition, the period between maintenance of the mechanical system is increased as a result of the smoothness in the changes of the loads at start-up and during the change of speed. In [30] a comparative analysis of life cycle and environmental impact costs is made when using variable speed drives using ecodesign methods evidencing environmental and energy benefits.

The objective of this work is to investigate the feasibility of the use of efficient drives in water systems to feed the boilers in the sugar industry adopting a strategy of flow control with constant pressure. As an object of study, a Cuban sugar industry is used. This type of study is of great importance for implementation of energy management systems, save energy and reduce CO2 emissions [31]-[33].

\section{RESEARCH METHOD}

\subsection{Problem statement}

In the sugar mills, the control of flow water is difficult because the pumping system is characterized by having a pump that supplies several steam generators connected in parallel, each working in different regimes, with different loops of water level control in the domes of each generator. In this type of system, the control is carried out with the help of the curves of pump and system simultaneously, guaranteeing the operation at the point where the load remains constant in any operating regime. 
The sugar industry in Cuba has the following characteristics:

a. It is a cyclical industry with a productive period of approximately $3000 \mathrm{~h}$ in the harvest stage followed by an inactive period. The limited annual hours of work negatively affect the profitability of investments focused on energy savings.

b. It is an industry with cogeneration, totally electrified and synchronized to the National Electric Power System (SEN), with the possibility of selling the excess energy to the grid at a differentiated tariff with time discrimination. This allows to value the energy savings based on the sale price of the energy generated in the industry, considering that the energy saved can be exported to the network producing additional income.

c. The water system to feed boilers is regulated in each steam generator independently, preventing the regulation of the total flow in the pump.

With these considerations the following methodology applied to a real case of study was followed:

a. Obtain the characteristic data of the hydraulic system and the pumps.

b. Select the working speed range of the pump to meet the flow demands.

c. Select the appropriate variable speed drive.

d. Estimate the annual energy savings through the use of this technology.

e. Carry out the economic feasibility analysis for possible scenarios.

\subsection{Case study initial conditions}

The feedwater system of the sugar mill, taken as a case study, has two MULTITEC pumps model C125 / 7-10.1, connected in parallel, one for work and the other for reserve. The pumps must operate at a pressure capable of overcoming the losses in the pipes and fittings, as well as the pressure drop in the economizer and in the water level regulating valve in the dome. The boiler feed water system must maintain the water level in the domes as a regulated system. In this system, the capacity is determined by the demand, and the flow is controlled by regulating the excess load developed by the pumps [34]. From the information of the pumping system components and applying the methodology described in [35], the equation of the hydraulic characteristic of the system as a function of the flow is obtained.

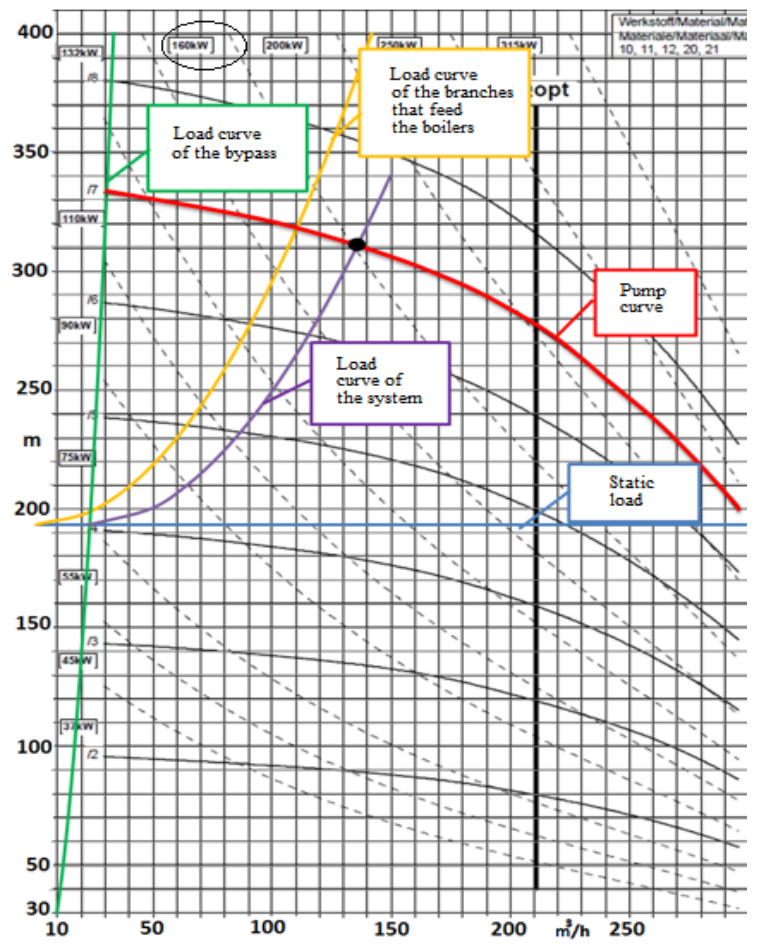

Figure 1. System and pump curves. Source: self made

The load curve of the feed water system is calculated for a nominal working flow of the boilers at $110 \mathrm{~m}^{3} / \mathrm{h}$. Figure 1 shows the system curve (static and dynamic load) and the pump curve. The static load indicated by the blue line is $193.17 \mathrm{~m}$. The load curve of the branches that feed the boilers, 
without considering the bypass, is represented in yellow color. The load curve of the bypass, to maintain the minimum necessary flow is indicated in green. The load curve of the complete system, obtained as the pointto-point sum of the two previous curves for each load value $\mathrm{H}$, is represented with violet color. The intercept of this curve with the pump characteristic (curve of red color) defines the operation point. For these design conditions, the flow delivered by the pumps is $135 \mathrm{~m}^{3} / \mathrm{h}$ with a load of $310 \mathrm{~m}$.

\subsection{Design conditions}

From the established operating point, the power delivered by the pump to the fluid can be calculated as:

$$
\mathrm{P}_{\text {useful }}=\frac{\rho \cdot \mathrm{g} \cdot \mathrm{Q} \cdot \mathrm{H}}{1000}
$$

where $\mathrm{P}_{\text {useful }}$ is the useful power that the pump delivers to the fluid, in $\mathrm{kW}$; $\boldsymbol{\rho}$ is the density of liquid, in $\mathrm{Kg} / \mathrm{m}^{3}$; $\mathrm{g}$ is the gravitational acceleration, in $\mathrm{m} / \mathrm{s}^{2}$; $\mathrm{Q}$ is the flow, in $\mathrm{m}^{3} / \mathrm{s}$ and $\mathrm{H}$ is the load, in $\mathrm{m}$.

Substituting the operation point data in (1), it is obtained that $\mathrm{P}_{\text {useful }}=109.03 \mathrm{~kW}$. The efficiency of the pump is calculated as:

$$
\eta_{\text {pump }}=\frac{P_{\text {useful }}}{P_{\text {brake }}}
$$

where $\mathrm{P}_{\text {break }}$ is the power that the pump demands from the motor, in $\mathrm{kW}$.

The value of $\mathrm{P}_{\text {break }}$ is a function of the operating point of the pump. In Figure 1 it can be seen indicated in a circle that this power is approximately $160 \mathrm{~kW}$. Therefore substituting in (2), it is obtained for these conditions that $\eta$ pump $=68.14 \%$. Table 1 shows the nominal data of the squirrel-cage motor that drives the pump.

\begin{tabular}{cc} 
Table 1. Nameplate Data of Motor \\
\hline Power (kW) & 200 \\
Frequency (Hz) & 60 \\
Speed (rpm) & 1790 \\
Voltage (V) & 480 \\
Power factor (p.u.) & 0.86 \\
Current (A) & 293 \\
Efficiency at 100\% of load & 95.5 \\
Efficiency at 75\% of load & 95.1 \\
\hline
\end{tabular}

The power delivered by the motor to the pump is $160 \mathrm{~kW}$, representing $80 \%$ load. From the values of motor efficiency at $75 \%$ and at $100 \%$ load; it can be estimated by interpolation that the operational efficiency of the motor at the actual load state $(80 \%)$ is $\eta_{\text {motor }}=95.18 \%$.

As can be seen, the motor works in design conditions of system with an efficiency close to the nominal. The value of the efficiency is high because it is a high efficiency motor (IE2). The energy consumption for a harvest in a year is determined as:

$$
\mathrm{E}=\frac{\mathrm{P}_{\text {breake }}}{\eta_{\text {motor }}} \cdot \mathrm{t}
$$

where $\mathrm{E}$ is energy consumption in $(\mathrm{kWh})$ and $\mathrm{t}$ is the operating time of the pump, in $\mathrm{h}$.

For a harvest of approximately 130 effective days, the operating time is $3120 \mathrm{~h}$, so according to (3), the estimated energy consumption is $524479.93 \mathrm{kWh} /$ harvest.

\section{RESULTS AND ANALYSIS}

\subsection{Solution proposal for the regulation of flow at constant load using variable speed drive}

According to [36], feedwater pumps must be capable of working at a pressure greater than $25 \%$ of the certified boiler pressure. Under current operating conditions, according to the historical information recorded in the SCADA measurement and control system installed, the pumps work between ( $260 \mathrm{~m}$ to $320 \mathrm{~m} \mathrm{load}$ ) and motor at a speed of $1792 \mathrm{rpm}$. For the proposed application, it is considered that the pumps work at a constant load of $280 \mathrm{~m}$ and the motor speed corresponds to any condition within hydraulic characteristic of the pump and is the maximum working speed. 
The variable speed drive must satisfy the water demand of the boilers, moving the operation point up to the constant load line, from a maximum speed to a minimum speed guaranteeing the minimum safe flow, as shown in Figure 2. In this figure, the characteristics of the pump for different working speeds are shown in parallel to the operating characteristic given by the manufacturer and corresponding to the maximum speed. The speeds of each curve are indicated as nmin, $\mathrm{n}_{1}, \mathrm{n}_{2} \ldots . \mathrm{n}_{\max }$.

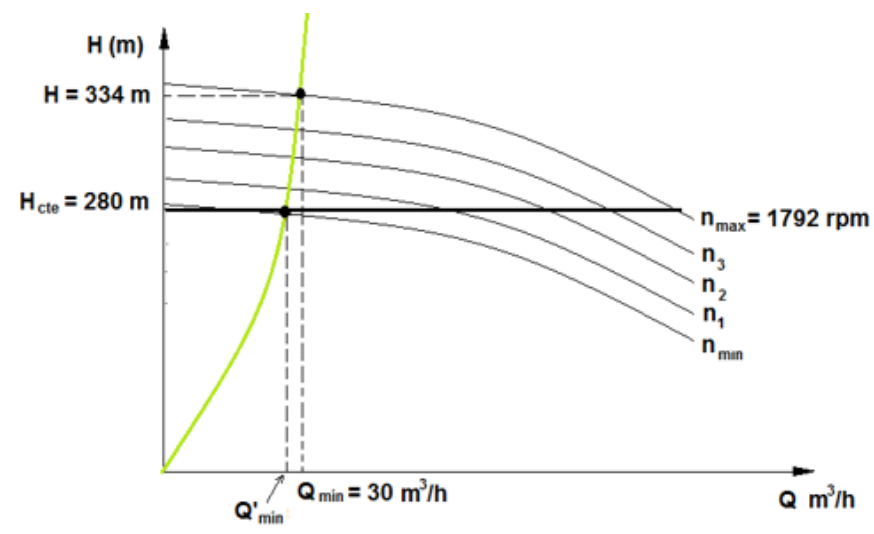

Figure 2. Characteristics of the pump for different speeds. Source: self-made

In Figure 2 the hydraulic load curve of the recirculation has been indicated in green. This curve corresponds to a quadratic expression of the form:

$$
\mathrm{H}=\mathrm{K} \cdot \mathrm{Q}^{2}
$$

Knowing that for safe minimum flow Qmin $=30 \mathrm{~m} 3 / \mathrm{h}$ at the maximum working speed, $\mathrm{H}=334 \mathrm{~m}$, from equation (5), the calculated coefficient $\mathrm{K}=0.371$. From this expression and for $\mathrm{H}=280 \mathrm{~m}$, Q'min $=$ $27.47 \mathrm{~m}^{3} / \mathrm{h}$. According to the affinity laws, the minimum speed is determined as:

$$
\mathrm{n}_{\min }=\mathrm{n}_{\max } \cdot \frac{\mathrm{Q}_{\operatorname{mín}}^{\prime}}{\mathrm{Q}_{\min }}=1792 \cdot \frac{27.47}{30} \approx 1640 \mathrm{rpm}
$$

The speed range calculated then is from 1640 to $1792 \mathrm{rpm}$. The selection of the variable speed drive is made considering the following key aspects:

a. Characteristics of the motor to be controlled: Power: $200 \mathrm{~kW}$, Nominal voltage: $480 \mathrm{~V}$, Nominal frequency: $60 \mathrm{~Hz}$, Nominal current: 293 A, Nominal speed: $1790 \mathrm{rpm}$.

b. Type of load: Load type centrifugal pump of variable moment.

c. Environmental and working conditions: Height above sea level below $1000 \mathrm{~m}$ and ambient temperature below $50{ }^{\circ} \mathrm{C}$. Located in a control room with good environmental conditions, absence of magnetic powders, conductive dust and dry environment.

d. Nominal network conditions: Nominal voltage: $480 \mathrm{~V}$ and Frequency: $60 \mathrm{~Hz}$.

e. Needs for the control: At least one analog input (signals from 0 to $10 \mathrm{~V} \mathrm{DC}$ or from 0 to $20 \mathrm{~mA} \mathrm{DC}$ ) to program the pressure reference to the variable speed drive.

Considering the above characteristics and the nominal current of the existing motor, an inverter MICROMASTER 440, Siemens, type 6SE64402UD413GAO, rated power $160 \mathrm{~kW}$, input current 296.4 A, output current $302 \mathrm{~A}$, size GX and weight of $190 \mathrm{~kg}$, was selected.

\subsection{Energy saving}

The use of a variable speed drive implicitly saves energy. The power required before and after varying the motor speed is calculated from the most probable flow rate that is supplied to the boilers. In the present case study, this flow is $65.87 \mathrm{~m}^{3} / \mathrm{h}$ according to the results of a statistical analysis based on the information registered by the SCADA system. Adding the recirculation flow rate of $30 \mathrm{~m}^{3} / \mathrm{h}$, a total of $95.87 \mathrm{~m} 3 / \mathrm{h}$ is obtained. The interception of this value with the pump characteristic of Figure 1 shows that the corresponding load is $\mathrm{H}=320 \mathrm{~m}$ and the power required by the pump is $132 \mathrm{~kW}$. 
Operating with variation of speed maintaining the constant load, the flow of water to feed $\left(95.87 \mathrm{~m}^{3} / \mathrm{h}\right)$ to $280 \mathrm{~m}$ of load, represents, according to the equation (2), a useful power supplied by the pump to the fluid of $69.93 \mathrm{~kW}$. Then for a $60 \%$ pump efficiency the mechanical power is $116.55 \mathrm{~kW}$. This power can also be obtained by interpolating the power curves in Figure 1 for the new operating point.

The electrical power demanded by the motor is calculated from the estimation of the efficiency in the two operating conditions (most probable current and future with inverter). For this, the load factor of the motor was determined in both cases as following:

a. Load factor of the motor $\left(\mathrm{Kc}_{\text {current }}\right)$ in the most probable current condition.

$$
\mathrm{Kc}_{\text {current }}=\frac{132 \mathrm{~kW}}{200 \mathrm{~kW}}=0.66
$$

b. Load factor of the motor in the most probable flow condition at constant load using variable speed drive $\left(\mathrm{Kc}_{\text {planned }}\right)$ :

$$
\mathrm{Kc}_{\text {planned }}=\frac{116.55 \mathrm{~kW}}{200 \mathrm{~kW}}=0.58
$$

Table 2 shows the efficiency for both cases obtained from linear interpolation from the data of Table 1.

\begin{tabular}{|c|c|c|}
\hline $\begin{array}{l}\text { Load factor } \\
\qquad(\%)\end{array}$ & $\begin{array}{l}\text { Motor } \\
\text { efficiency } \\
\quad(\%)\end{array}$ & $\begin{array}{c}\text { Efficiency } \\
\text { Set Motor- Variable speed } \\
\text { drive } \\
(\%)\end{array}$ \\
\hline 0.66 & $94.83 \%$ & - \\
\hline 0.58 & $94.82 \%$ & $91.98 \%$ \\
\hline
\end{tabular}

Table 2. Motor Efficiency in both Cases

The efficiency of the variable speed drive ( $\eta v s d)$ is $97 \%$, according to the manufacturer's technical specifications. The reduction of instantaneous electric power demanded is estimated as:

$$
\Delta \mathrm{P}=\mathrm{P}_{\mathrm{nom}} \cdot\left(\frac{\mathrm{Kc}_{\text {current }}}{\eta_{\text {motor }}}-\frac{\mathrm{Kc}_{\text {planned }}}{\eta_{\text {motor }} \cdot \eta_{\mathrm{vsd}}}\right)=200 \cdot\left(\frac{0.66}{0.9483}-\frac{0.58}{0.9482 \cdot 0.97}\right)=13 \mathrm{~kW}
$$

The energy saved annually considering a harvest of 130 days and $85 \%$ of non-stop use, is calculated as:

$$
\Delta \mathrm{E}=\Delta \mathrm{P} .24 \frac{\mathrm{h}}{\text { día }} \cdot 130 \frac{\text { día }}{\text { año }} \cdot 0.85=3 \mathrm{~kW} \cdot 24 \frac{\mathrm{h}}{\text { día }} \cdot 130 \frac{\text { día }}{\text { año }} \cdot 0.85=34230.51 \frac{\mathrm{kWh}}{\text { año }}
$$

As the sugar mill is synchronized with the SEN and exports the surplus energy, the saving of electrical energy using the variable speed drive can be sold. Therefore, revenues are calculated according to the average sale price of electric power.

\subsection{Environmental benefit}

The environmental impact due to the use of the variable speed drive, due to energy saving, is the potential to reduce greenhouse gases or other elements that cause negative impact to the environment. The increase in energy efficiency in the sugar industry has an environmental benefit because the energy saved can be exported to the SEN. Thus, the energy generated with fossil fuel is replaced by energy produced from biomass.

In the case of Cuba, the potential mitigation of $\mathrm{CO}_{2}$ emissions for energy saving projects can be calculated by the emission index of $0.794 \mathrm{t} / \mathrm{MWh}$ estimated by methodology proposed in [37]. As the annual energy saving potential is $34230.51 \mathrm{kWh}$, then the potential for mitigating $\mathrm{CO}_{2}$ emissions is $27.17 \mathrm{t} /$ year.

\subsection{Economic analysis}

The economic analysis and the feasibility of the investment were made using discounted flow techniques, specifically the Net Present Value (NPV) and the Payback Period (PP). The economic data used are:

a. Useful life: 10 years. 
b. Initial investment, mainly due to the acquisition cost of the variable speed drive: 16951.54 USD.

c. Energy sale price: 0.0877 USD / kWh,

d. Bank interest rate: $8 \%$ [38].

e. Tax on profits: $35 \%$ [39]

f. Energy inflation: $3 \%$.

g. Risk margin: $2 \%$.

h. Depreciation is considered linear.

The cash flow for each year i after taxes is calculated as:

$$
\mathrm{FC}_{\mathrm{i}}=\left(\left(\Delta \mathrm{E}_{\mathrm{i}} \cdot \mathrm{Ce}\right)-\mathrm{Dep}\right) \cdot\left(1-\frac{\mathrm{I}}{100}\right)+\mathrm{Dep}
$$

where $\mathrm{I}$ is the tax rate; Dep is depreciation, and it is calculated as Dep $=\frac{\mathrm{Io}}{\mathrm{n}}$; Io is the initial investment, in USD; Ce is the price of energy, equal to the average sale price $(0.0877 \mathrm{USD} / \mathrm{kWh})$ and $\Delta \mathrm{Ei}$ is the energy saved in the year $\mathrm{i}$, in $\mathrm{kWh} /$ year, iqual to $34230.51 \mathrm{~kW} /$ year.

To update the cash flows until the year in which the investment is made, the discount factor for each year $\mathrm{i}$ is calculated as:

$$
\mathrm{FCD}_{\mathrm{i}}=\mathrm{FC}_{\mathrm{i}} \cdot \mathrm{FD}_{\mathrm{i}}
$$

The discount factor for a bank interest rate $\mathrm{r}$ is calculated as:

$$
\mathrm{FD}_{\mathrm{i}}=\frac{1}{\left(1+\frac{\mathrm{r}}{100}\right)^{\mathrm{i}}}
$$

The NPV is equal to the sum of all the discounted cash flows during the useful life of the investment, expressed as:

$$
\mathrm{NPV}=-\mathrm{Io}+\sum_{\mathrm{i}=1}^{\mathrm{n}} \mathrm{FCD}_{\mathrm{i}}
$$

The Net Present Value was 301.56 USD and the PP were 9.78 years. These results show that the investment is profitable since the NPV is positive, but not attractive because its value is small, and the investment is recovered at the end of the useful life of the equipment. This is due to the high initial investment cost and the reduced energy savings achieved annually since the sugar industry in Cuba is cyclical with only 130 days of operation per year approximately.

However, if it is considered that the energy saved replaces the use of fossil fuel, since it is generated from biomass, the same analysis can be carried out from a non-business perspective, but at the level of a government program. This means that if the energy price of the SEN is considered, that is, $0.21 \mathrm{USD} / \mathrm{kWh}$,

\begin{tabular}{|c|c|c|c|c|}
\hline Scenarios & $\begin{array}{c}\text { Energy } \\
\text { saving, } \\
\Delta \mathrm{E} \\
\text { (kWh/year) }\end{array}$ & $\begin{array}{c}\text { Energy } \\
\text { prices } \\
\text { (USD/kWh) }\end{array}$ & VPN (USD) & $\begin{array}{c}\mathrm{PP} \\
\text { (years) }\end{array}$ \\
\hline \multirow{2}{*}{$\begin{array}{l}\text { Business focus } \\
\text { Government } \\
\text { focus }\end{array}$} & 34230.51 & 0.08 & 301.56 & 9.78 \\
\hline & 34230.51 & 0.21 & 19277.60 & 3.87 \\
\hline
\end{tabular}
the NPV is 19277.60 USD and the PP is 3.87 years. Table 3 summarizes the results of the economic analysis for these two scenarios.

Table 3. Results of the Economic Analysis for the two scenarios

Of the economic variables used, the energy price and the discount rate are variable. The first depends on the variations in the price of fuel in the international market and the second in the sector of the economy that is analyzed and the investment policy of the country. Variations in the price of energy can be considered by varying the rate of energy inflation; and variations in the discount rate, varying the risk margin. In this way, a sensitivity analysis of the investment profitability can be made with the variations of these economic variables. The results of the NPV sensitivity analysis are shown in Figure 3, both for the case 
of business focus and for a governmental focus. Figure 4 shows how the PP varies for these scenarios with variations of the same variables.

As can be seen, throughout the range of variation of the economic variables analyzed, the PP is always high for the company, however, with the government focus it is feasible because it is in the order of four years.

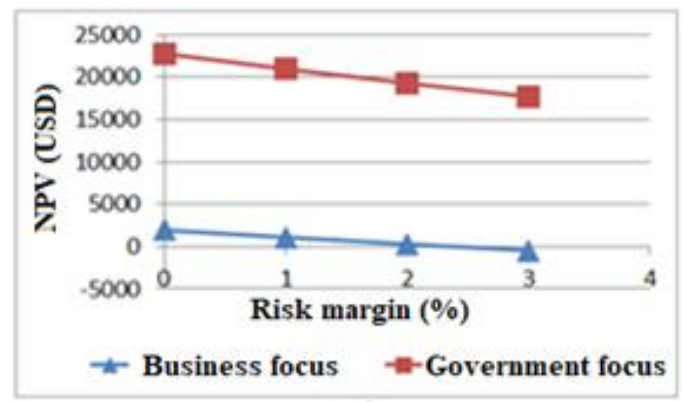

(a)

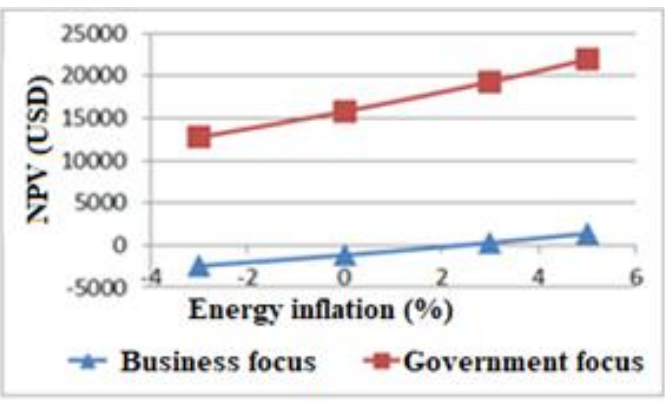

(b)

Figure 3. NPV calculated (a) for different values of the risk margin and (b) for different values of the inflation rate

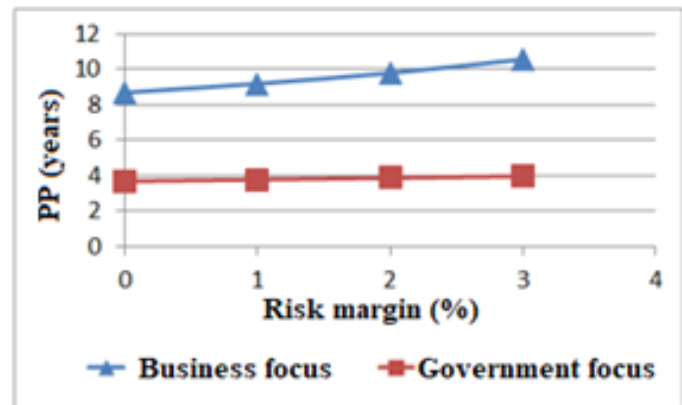

(a)

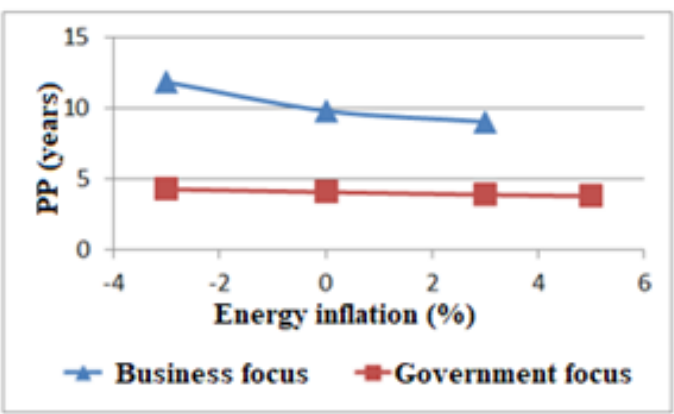

(b)

Figure 4. PP calculated (a) for different values of the risk margin and (b) for different values of the inflation rate

\section{CONCLUSION}

The study demonstrated the technical feasibility of using variable speed drive in water pumping systems to feed boilers in the sugar industry. For the proposed application, a MICROMASTER 440 inverter from Siemens, type 6SE64402UD413GAO, nominal power $160 \mathrm{~kW}$, output current $302 \mathrm{~A}$. With this device, it is proposed to implement a strategy of variable flow control at constant load.

The estimated savings potential using this technology is $34230.51 \mathrm{kWh} /$ year, which means that 27.17 tons of $\mathrm{CO}_{2}$ per year are no emitted into the atmosphere. However, it is shown that the investment proposal for the company is not attractive, since the period of recovery of the investment approaches the end of the useful life considered ( 9.78 years). A different way to evaluate the proposal is to analyze the economic feasibility with a governmental focus. For this, the cost of electricity generation is 0.21 USD, instead of 0.08 USD used for the business approach. In this scenario, the investment recovers in 3.87 years. This type of analysis can be applied to other cyclical industries with a low annual operating period.

This result also demonstrates that for the implementation of measures to save energy or generate energy from renewable sources, it is necessary that governments apply incentive policies.

\section{REFERENCES}

[1] US Energy Information Administration, "DOE/EIA-0484 International Energy Outlook 2016 with Projections to 2040," May 2016. 
[2] A. Dietmair and A. Verl, "Energy Consumption Assessment and Optimisation in the Design and use Phase of Machine Tools," in Proceedings of the 17th CIRP International Conference on Life Cycle Engineering, 2010, pp. 116-121.

[3] S. P. Singh, "Technical Change and Productivity Growth in the Indian Sugar Industry," Procedia Economics and Finance, vol. 39, pp. 131-139, 2016.

[4] M. Morato, et al., "Future Hybrid Local Energy Generation Paradigm for the Brazilian Sugarcane Industry Scenario," International Journal of Electrical Power \& Energy Systems, vol. 101, pp. 139-150, 2018.

[5] J. Q. Albarelli, et al., "Product Diversification To Enhance Economic Viability of Second Generation Ethanol Production in Brazil: The Case of the Sugar and Ethanol Joint Production," Chemical Engineering Research and Design, vol. 92, no. 8, pp. 1470-1481, 2014.

[6] M. K. Chauhan, et al., "Life Cycle Assessment of Sugar Industry: A Review," Renewable and Sustainable Energy Reviews, vol. 15, no. 7, pp. 3445-3453, 2011.

[7] S. Sathitbun-anan, et al., "Energy Efficiency and Greenhouse Gas Emission Reduction Potentials in Sugar Production Processes in Thailand," Energy for Sustainable Development, vol. 23, pp. 266-274, 2014.

[8] E.C., Quispe, et al., "Unbalanced Voltages Impacts on the Energy Performance of Induction Motors," International Journal of Electrical and Computer Engineering (IJECE), vol. 8, no. 3, pp. 1412-1422, 2018.

[9] V. Sousa, et al., "Estimating Induction Motor Efficiency under no-controlled Conditions in the Presences of Unbalanced and Harmonics Voltages," in 2015 CHILEAN Conference on Electrical, Electronics Engineering, Information and Communication Technologies (CHILECON), Santiago, 2015, pp. 567-5.

[10] V. Sousa, et al., "Shaft Power Estimation in Induction Motor Operating under Unbalanced and Harmonics Voltages," IEEE Latin America Transactions, vol. 14, no. 5, pp. 2309-2315, 2016.

[11] M. Koor, et al., "Optimization of Pump Efficiencies with different Pumps Characteristics Working in Parallel Mode," Advances in Engineering Software, vol. 101, pp. 69-76, 2016.

[12] V. Sousa, et al., "Harmonic Distortion Evaluation Generated by PWM Motor Drives in Electrical Industrial Systems," International Journal of Electrical and Computer Engineering (IJECE), vol. 7, no. 6, pp. 3207-3216, 2017.

[13] V. Sousa, et al., "Analysis of Harmonic Distortion Generated by PWM Motor Drives," in 2017 IEEE Workshop on Power Electronics and Power Quality Applications (PEPQA), Bogota, 2017, pp. 1-6.

[14] P. Olszewski, "Genetic Optimization and Experimental Verification of Complex Parallel Pumping Station with Centrifugal Pumps," Applied Energy, vol. 178, pp. 527-539, 2016.

[15] M. D. Z. Izquierdo and J. J. S. Jiménez, "Operación óptima de bombas en paralelo empleando variadores de velocidad," Ingenierías, vol. 13, no. 46, p. 57, 2010.

[16] Z. Ma and S. Wang, "An Optimal Control Strategy for Complex Building Central Chilled Water Systems for Practical and Real-time Applications," Building and Environment, vol. 44, pp. 1188-1198, 2009.

[17] S. Wang, "Intelligent Buildings and Building Automation," Spon Press, London, 2010, pp. 203.

[18] M. I. Jahmeerbacus, "Flow Rate Regulation of a Variable Speed Driven Pumping System using Fuzzy Logic," in 4th International Conference on Electric Power and Energy Conversion Systems (EPECS), Sharjah, United Arab Emirates, 2015.

[19] C. A. Solano, et al., "Sistema de control de presión para el suministro de agua en la central de servicios del centro médico nacional la raza," México, 2012.

[20] J. A. Saavedra, "Control de presión mediante variador de frecuencia y motobomba," Chile, 2007.

[21] R. A. Castillo, “Automatización del sistema de bombas de agua fría de fábrica de tejidos imperial S. A.," 2009.

[22] J. J. García, et al., "Modelado y simulación de una bomba centrífuga con motor monofásico en Simulink," Revista Colombiana de Tecnologías de Avanzada, vol. 2, no. 22, pp. 78-84, 2013.

[23] P. Gómez, et al., "Procedimiento para la selección de la estrategia de regulación más adecuada en estaciones de bombeo," in IV Jornadas de Ingeniería del Agua, JIA 2015, Córdoba, España, 2015, pp. 1191-1202.

[24] H. Díaz, et al., "Diseño de un sistema de control para obtener presión constante de agua," in XXII Congreso Internacional de Ingeniería Eléctrica, Electrónica, Computación y Afines, Huancayo, Perú, 2015.

[25] F. E. Hoyos, et al., "Selection and Validation of Mathematical Models of Power Converters using Rapid Modeling and Control Prototyping Methods," International Journal of Electrical and Computer Engineering (IJECE), vol. 8, no. 3, pp. 1551-1568, 2018.

[26] J. R. Gómez, et al., "Experiencia de aplicación de accionamiento de velocidad variable. opción de alto comportamiento para la gestión energética," in 48 Congreso de la ATAC, La Habana, 2002.

[27] Y. Delgado, "Estudio de factibilidad técnico-económica de regulación de la capacidad con variadores de frecuencia de las bombas de agua de alimentar de la CTE ‘Carlosma Manuel de Céspedes'. Cienfuegos. Cuba,” 2014.

[28] V. A. Shankar, et al., "Real Time Simulation of Variable Speed Parallel Pumping System," Energy Procedia, vol. 142, pp. 2102-2108, 2017.

[29] J. Viholainen, "Energy-efficient Control Strategies for Variable Speed Driven Parallel Pumping Systems based on Pump Operation Point Monitoring with Frequency Converters," Act Universitatis Lappeenrantaensis, 2014.

[30] F. J. Ferreira, et al., "Ecoanalysis of Variable-speed Drives for Flow Regulation in Pumping Systems," IEEE Transactions on Industrial Electronics, vol. 58, no. 6, pp. 2117-2125, 2011.

[31] J. A. Madrigal, et al., "Planificación energética para el ahorro de fueloil en una lavandería industrial," Ingeniare. Revista chilena de ingeniería, vol. 26, no. 1, pp. 86-96, 2018.

[32] A. Sagastume, et al., "Electricity Management in the Production of Lead-acid Batteries: The Industrial Case of a Production plant in Colombia," Journal of Cleaner Production, vol. 198, no. 10, pp. 1443-1458, 2018. 
[33] J. R. Gómez, et al., "A New Energy Performance Indicator for Energy Management System of a wheat mill plant," International Journal of Energy Economics and Policy, vol. 8, no.4, pp. 324-330, 2018.

[34] I. J. Karassik and R. Carter, "Bombas centrífugas. Selección, operación y mantenimiento," Companhia Editorial Continental, 1966.

[35] Crane Co., "Flujo de fluidos en válvulas, accesorios y tuberías," McGRAW-HILL, 1977.

[36] E. Hugot, "Handbook of Cane Sugar Engineering," New York: Elsevier, 1986.

[37] I. Salazar, et al., "Estimado de la reducción de la emisión de $\mathrm{CO} 2$ por accione de ahorro de electricidad en las condiciones de Cuba,” Ingeniería Energética, vol. 31, no. 3, pp. 1-5, 2010.

[38] Banco Central de Cuba, Circular 5/2011 y Circular 2/2012, La Habana, Cuba.

[39] Gaceta Oficial de la República de Cuba, Ley 113, artículo 97, La Habana, Cuba, 2012.

\section{BIOGRAPHIES OF AUTHORS}

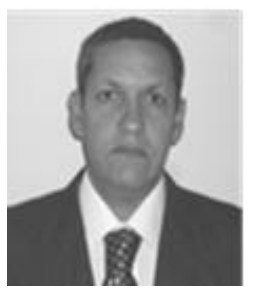

Julio R. Gómez Sarduy was born in 1963 in Cienfuegos, Cuba. Received the B.S degree in electrical engineering from Universidad Central de Las Villas, Santa Clara, Cuba, in 1986. Received the M.Sc. degree in electrical engineering from Universidad Central de Las Villas, Santa Clara, Cuba, in 1996, from there he received his Ph.D. degree in 2006. Currently is with the Center for the Study of Energy and Environment (CEEMA). Faculty of Engineering, Universidad de Cienfuegos, Cienfuegos, Cuba. His area of interest includes electric machines, power quality and energy efficiency in industrial power systems.

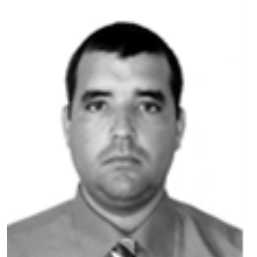

Vladimir Sousa Santos was born in Cienfuegos, Cuba on November 21, 1980. Received the B.S degree in Electrical Engineering from Universidad Central de Las Villas, Cuba, in 2004. Received the M.Sc. degree in Energy Efficiency from Universidad de Cienfuegos, Cuba, in 2006. Received the Dr.C. (Ph.D.) degree from Universidad Central de Las Villas, Cuba, in 2014. Currently is with GIOPEN of Energy Department of Universidad de la Costa (CUC), Colombia. His area of interest includes electric machines, power quality and energy efficiency.

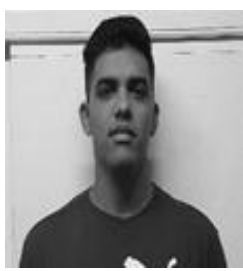

Mario S. Quintana Valladares was born in Cienfuegos, Cuba, on February 22, 1993. He received the title of Mechanical Engineer in 2017, at the University of Cienfuegos, Cuba. Currently is with the research center (CEEMA) of the University of Cienfuegos, Cuba. He specializes in the mechanical areas of fluids and efficient energy management.

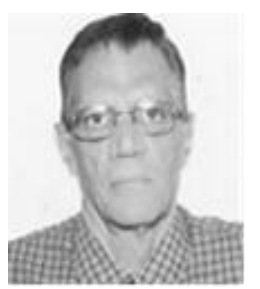

Percy R. Viego Felipe was born in Cienfuegos, Cuba on November 19, 1944. Received the B.S. degree in Electrical Engineering from the Universidad Central de Las Villas, Santa Clara, Cuba, in 1965. Received the Dr.C. (Ph.D.) degree from the Central Universidad Participated in a postdoctoral scholarship on single-phase induction machine design at the Lappeenranta University of Technology, Finland, in 1994. Currently is with the Center of Energy and Environmental Studies (CEEMA), Faculty of Engineering, Universidad de Cienfuegos, Cuba.

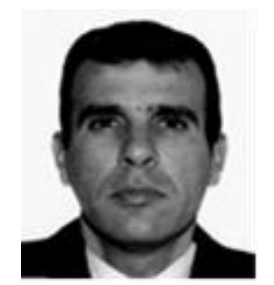

Hernan Hernández Herrera was born in Cienfuegos, Cuba on July 7, 1976. Received the B.S degree in Mechanical Engineering from the Universidad de Cienfuegos, Cuba in 2000. M. Sc. in applied mechanics from the Universidad de Cienfuegos, Cuba 2005. Received the Dr.C. (Ph.D.) degree from the Universidad de Cienfuegos, Cuba, in 2006. Currently is with Facultad de Ingenierias, Universidad Simon Bolivar, Colombia. His area of interest includes applied mechanics and energy efficiency.

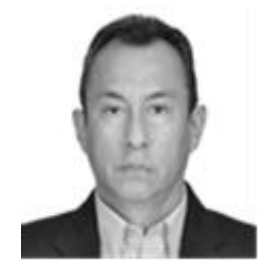

Enrique C. Quispe (M'95. SM'12) was born in Lima, Perú, on January 20, 1956. He received the B.Sc. in Electrical Engineering from the Universidad Nacional de Ingeniería, Perú in 1980. M.Sc. in Electrical Engineering, M. Eng. in Industrial Automation and PhD. in Electrical Engineering from Universidad del Valle, Colombia in 1994, 1997 and 2011, respectively. Since 1992, he has been with Universidad Autónoma de Occidente, Cali, Colombia, where he is currently Full Professor in the Department of Energy and Mechanics and the Director of the Energy Research Group. His current research interests include the analysis of electrical machines and drives, power quality and management and energy efficiency. He is an IEEE Senior Member. 